\title{
Analysis Implementation of Occupational Health and Safety Management System in Building Construction Project at "7 in 1" Project, Yogyakarta State University
}

\author{
Adityawan Sigit ${ }^{1, *}$ and Aristya Noor Azizah ${ }^{2}$ \\ ${ }^{1}$ Lecture Staff of Civil Engineering Study Program, Faculty of Civil Engineering and Planning, \\ Universitas Islam Indonesia, Indonesia \\ ${ }^{2}$ Undergraduate Student of Civil Engineering Study Program, Faculty of Civil Engineering and \\ Planning, Universitas Islam Indonesia, Indonesia
}

\begin{abstract}
In Indonesia, one of the guidance of Occupational Health and Safety Management System (OHSMS) is regulated in the Minister of Labor Regulation number PER. 05/MEN/1996. This research aims to find out and analyze about the representation of OHSMS on "7 in 1" Project, Yogyakarta State University, based on this regulation. The method used in this research is a quantitative method that is by direct observation in the field and descriptive qualitative method that tends to use analysis. As for the data collection in this research by doing interviews or unstructured interviews that intend to obtain information about the implementation of OHSMS in related projects. Data related to the OHSMS that has been obtained later will be discussed and will be compared with the Minister of Labor Regulation. Based on the research that has been done, it can be concluded that the OHSMS in "7 in 1" Project has implemented the OHSMS according to PER. 05/MEN/1996. However, due to several factors, there are cases that cause the OHSMS implementation is less than maximum, so it is necessary to increase the implementation of OHSMS in the field to minimize accident at the construction project site.
\end{abstract}

\section{Preface}

\subsection{Background}

Indonesia is one of Archipelago Countries from Sabang to Merauke, where the unequal population distribution in Indonesia causes high population density, especially in Java Island. This certainly affects development needs levels of structures and infrastructure in Java Island one of them is in Yogyakarta. Along with the increasing requirement of infrastructure structure construction, development problem and its relation with

\footnotetext{
*Corresponding author: adityawan.sigit@uii.ac.id
} 
Occupational Health and Safety (OHS) practice challenge that will be faced also more complex. Poor OSH implementation can damage the Occupational Health and Safety Management System ( OHSMS) in related projects. The OHSMS is a part of the overall management system that includes the organizational structure, planning, responsibility, implementation, procedures, processes and required resources for the development, implementation, achievement, control of risks related to work activities, in order to create safe, efficient and productive workplace (Endroyo, 2006).

As one of the ongoing development projects in Yogyakarta, the "7 in 1" Project, Yogyakarta State University has a zero accident target with no danger to workers, employees, and visitors who are coming to the project site. For that, we need to do a research on OHSMS in "7 in 1" Project so that in the future it can be done to minimize work accidents and also create a safe working environment.

\subsection{Research Purpose}

The aim of this research is capable to know and analyze about the implementation of Occupational Health and Safety Management System or as known as OHSMS at "7 in 1" Project, Yogyakarta State University.

\section{Research Methods}

\subsection{Type, Subject, and Object of Research}

The method used in this research is a descriptive qualitative method. It aims to know and analyze the implementation of Occupational Health and Safety Management System ( OHSMS) in the "7 in 1" Project, Yogyakarta State University. How to find out how high the quality of the safety management system at the "7 in 1" Project is by comparing it with Indonesian Occupational Safety Regulation number PER. 05/MEN/1996. There are 5 basics criteria on PER. 05/MEN/1996 regulation:

1. Commitment and Policy

2. Planning

3. Implementation

4. Measurement and Evaluation

5. Review and Improvement by Management

The subject of this research focuses on the implementation of OHSMS, the object of this research is "7 in 1" Project, and the main research is comparison between OHSMS in "7 in 1" Project and Occupational Safety Regulation number PER. 05/MEN/1996. 


\subsection{Research Stages}

Stages in the research can be seen in the following flowchart.
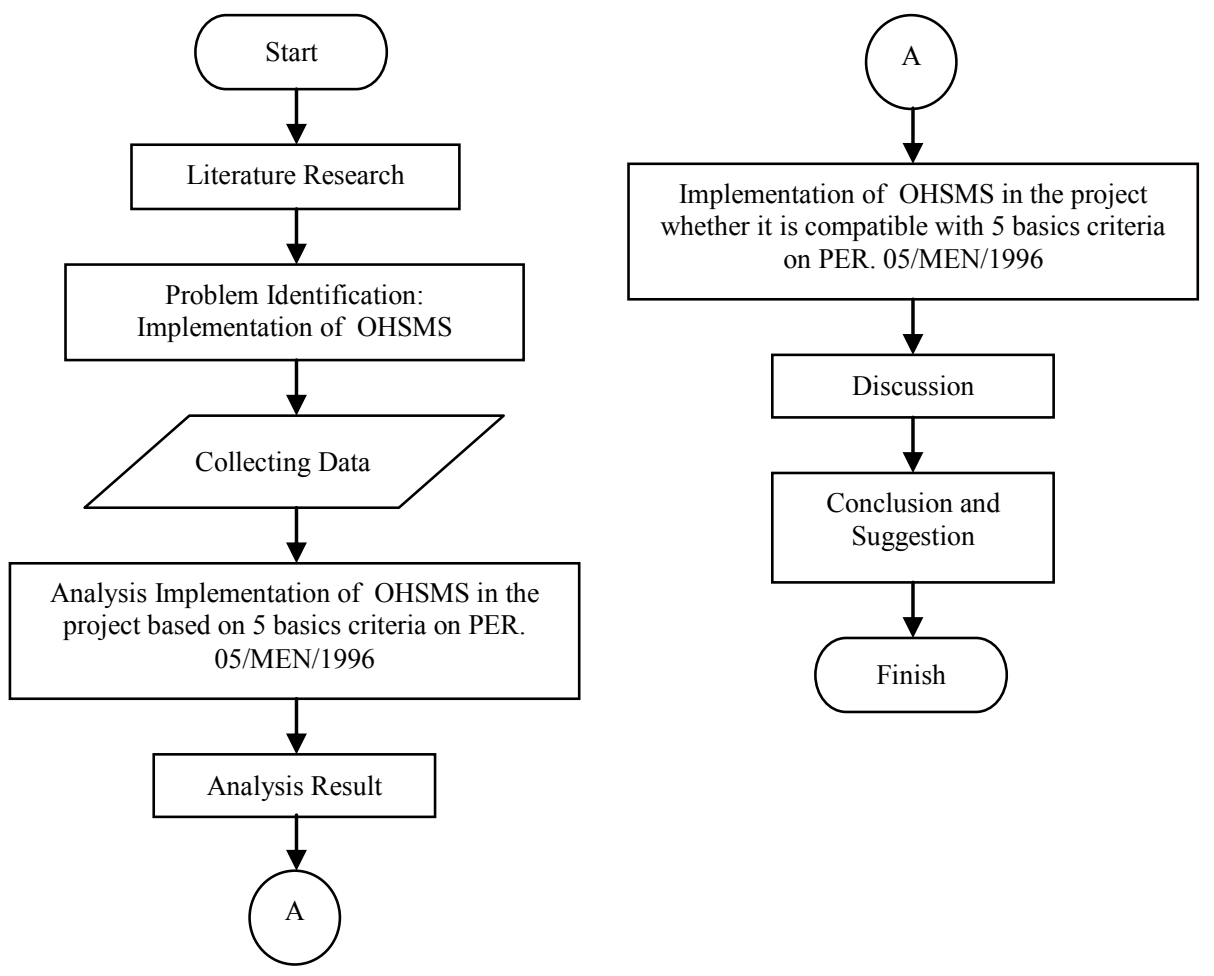

Fig. 1. Research Flowchart

\section{Analysis and Discussion}

\subsection{Data of Research Result}

At this stage, research data relating to OHSMS on "7 in 1" Project, Yogyakarta State University, is obtained. The data are in the primary and secondary form data that will be analyzed by comparing the implementation of OHSMS in the project related to the 5 main principles of Minister of Labor and Transmigration regulation number PER. 05/MEN/1996.

\subsubsection{General View of Project}

The "7 in 1" Project is a new building work that includes Structural, Architectural, Mechanical, and Electrical Work. This project consists of 12 buildings, in which each of it consists of 3 to 4 floors, roof, and 1 basement. The research itself is conducted on all of the new building constructions that are 12 buildings in 3 zones. Data about the project profile can be seen as follows. 
Table 1. Project Profile

\begin{tabular}{|l|l|}
\hline Name & "7 in 1" Project \\
\hline Location & $\begin{array}{l}\text { Jl. Colombo, Caturtunggal, Sleman, D.I. Yogyakarta - 55281 (in front of } \\
\text { UNY Hotel), Phone : (0274) 2920571 }\end{array}$ \\
\hline Contract Number & 027/ UN34.05/ LK/ KONTRAK/ PPK/ 2017 \\
\hline Date & July $14^{\text {th }}, 2017$ \\
\hline Contract Type & Unit price and lump sum \\
\hline Proprietor & Yogyakarta State University (Universitas Negeri Yogyakarta) \\
\hline $\begin{array}{l}\text { Planning } \\
\text { Consultant }\end{array}$ & $\begin{array}{l}\text { PT. Pola Data Consultant } \\
\text { PT. Widha Konsultan, Jo }\end{array}$ \\
\hline MK consultant & PT. Cakra Manggilingan Jaya and Adhicipta Engineering Consultant, Jo \\
\hline Contractor & PT. Waskita Karya (Persero), Tbk \\
\hline Time & 420 calendar days \\
\hline
\end{tabular}

\subsubsection{OHSMS Policy in "7 in 1" Project}

On this project, PT. Waskita Karya (Persero) Tbk uses several local policies or regulations where the regulations are made under the OHSAS standard 18001: 2007, ISO 14001: 2004 and ISO 9001: 2008, SMK3 PP. 50 of 2012, and PERKAP 24: 2007, that is used during the beginning of the project to completion.

PT. Waskita Karya (Persero) Tbk, as a construction services company, it always controls the risks toward safety, health, environment, quality, and security by applying Waskita Management System Policy to fulfill the satisfaction of stakeholders. For some policies on the project, it can be summarized as follows.

1. Obey the regulation laws and other applicable terms.

2. Improve the performance on an ongoing basis.

3. Prevent injuries, disease because of work, environmental pollution and the occurrence of security incidents that affect the company's business process.

4. Provide training, provide healthy, safe and comfortable work site and work facilities to all of the stakeholders.

The application scope of the policy covers all of the working activities in the "7 in 1" Project, for example to the employer, Waskita Karya Contractor, Sub Contractor, Supplier, and the surrounding environment that gets affected by the activities in this project.

\subsection{Comparison between Implementation of OHSMS in "7 in 1" Project and PER.05/MEN/1996}

Based on the data analysis that has been done, it was found the comparison between the implementation of Safety and Health Management System in "7 in 1" Project with the regulation number PER.05/MEN/1996 


\subsubsection{Commitment and Policy}

1. Leadership and commitment have been applied, proofs:

a. There is Hazzard Identification Risk Assessment Determining Control (HIRADC) form.

b. There is a performance assessment.

2. Initial review of OHS has been applied, proofs:

a. Identification of danger related to company activities.

b. There is knowledge and standards level assessment of OHS.

3. OHS Policy

It has been applied, proved by the company's policy documents.

\subsubsection{Planning}

1. Planning of Hazard Identification Risk Assessment Determining Control (HIRADC) It has been applied, proved by HIRADC and IADL (Identifikasi Aspek \& Dampak Lingkungan/ Environmental Impact Analysis).

2. Legislation and other requirements.

It has been applied, proved by the form of legislation list.

3. Goals and Objectives.

It has been applied, proved by the purpose and the objectives on OHS.

4. Performance Indicators.

It has been applied, proved by the form of OHS performance assessment.

5. Initial planning and ongoing activity planning.

It has been applied, proved by the purpose and objectives of OSH (K3).

\subsubsection{Implementation}

1. Capability Guarantee

a. Human resources, facilities, and funds

Human resources, facilities, and funds have been applied, proved by the provisions of communication concerning information about OHS effectively and the existence of regulations for the implementation of consultation and the involvement of active labor.

b. Integration

The Integration itself has been applied, proved by purposes and priorities of OHSMS as outlined in company's policy.

c. Responsibility and accountability

Responsibility and accountability have been applied, by the establishment of an Environment, Health, Safety (EHS) organization on projects that will hold the responsibility to understand and apply all of the applicable policies and procedures.

d. Consultation, motivation, and awareness. It has been applied as proved in Figure 2 and Figure 3.

e. Training and work competence

It has been applied, proved by the proposal of training form that was made based on the EHS competence standard that has been applied in the project. 


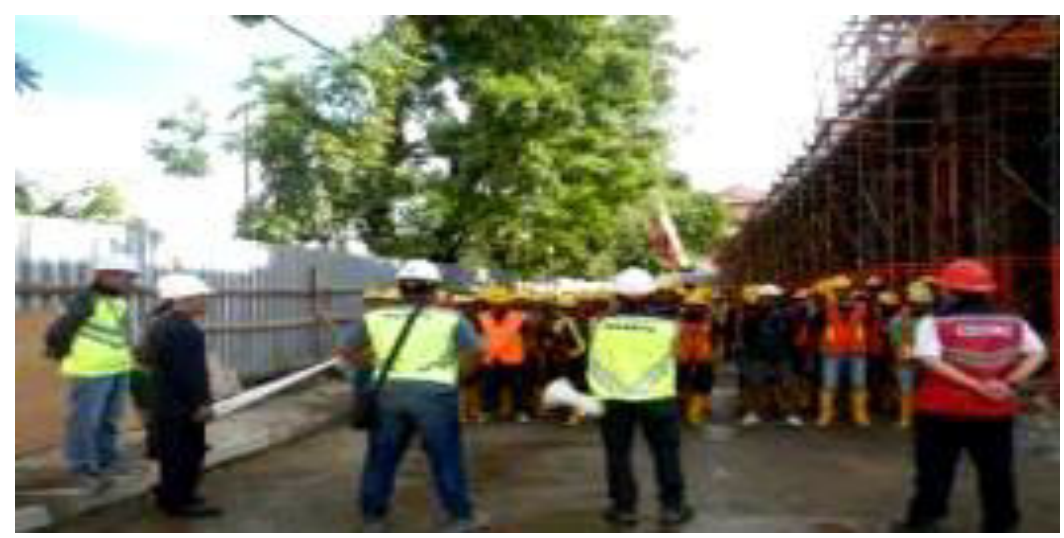

Fig. 2. Safety briefing

2. Supporting Activity

a. Communication

It has been applied, proved by all of the information about OHS in "7 in 1" project has been informed to all of the employees and worker.

b. Reporting

It has been applied, proved by OHS report through OHS Weekly Report, OHS Monthly Report, and OHS Inspection.

c. Documenting

It has been applied, proved by all of the OHS data and information are available and well managed, it can be accessed easily and evaluated periodically.

d. Document Control

It has been applied, proved on well-controlled procedures for information documented by the project part and also the document stamp form and document removal form.

e. Recording and Information Management

It has been applied, proved by the existence of the requirements or regulations about OHS and the OHS Work Permission System on the Project.

3. Hazard sources identification, assessments and risk control

a. Identify the source of the hazard

b. Risk assessment

c. Control measures

Some of them have been applied because the existence of HIRADC, proves that the "7 in 1" Project has carried out the identification of hazard sources, risk assessment, and risk control. However, at the stage of Control Measures that is conducted to control the risk of occupational incidents and accidents and occupational diseases, there are incompatibilities due to less than the maximal implementation of OHSMS in the project. Pictures of the incompatibility as shown below. 


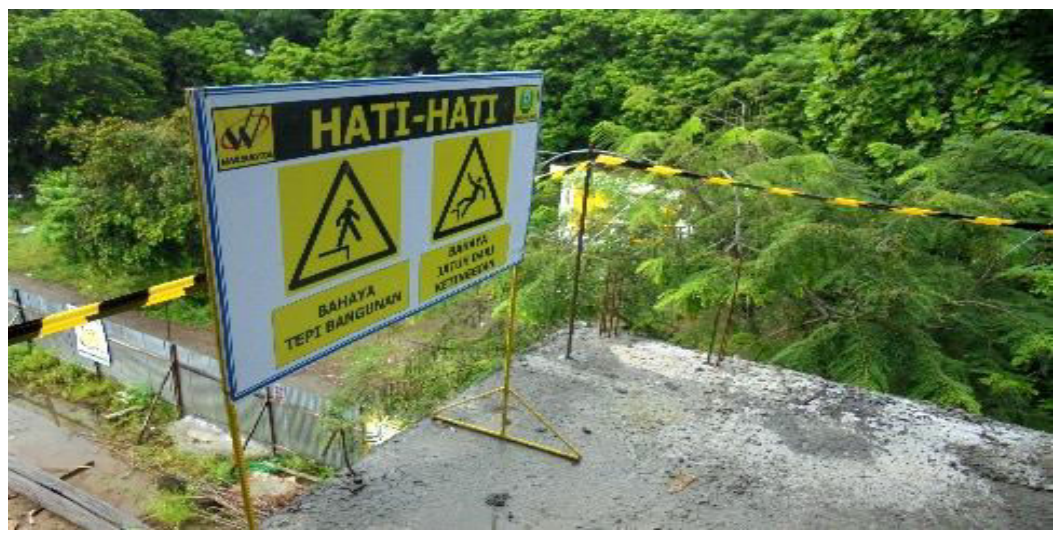

Fig. 3. Incorrect Sign placement

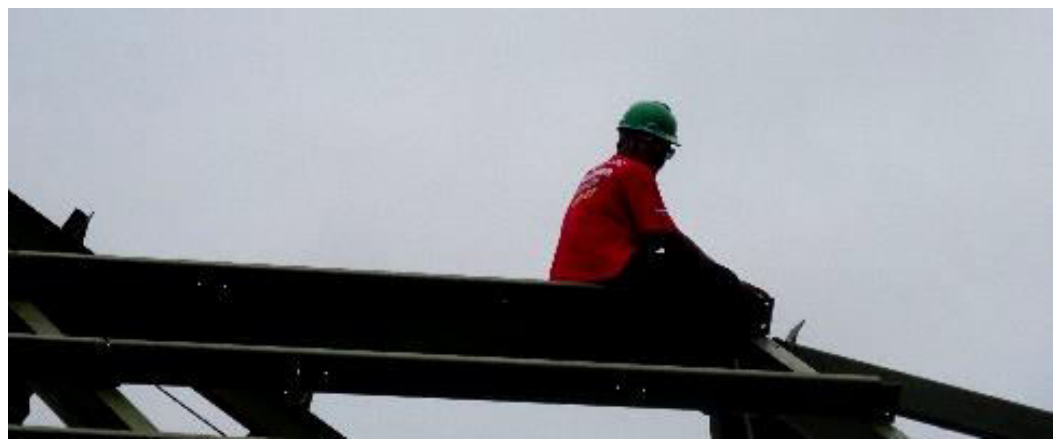

Fig. 4. Incomplete Personal Protective Equipment (PPE) on worker

These pictures above can be caused by several factors:

- Lack of supervision control

- Lack of knowledge about OHS

- Not disciplined habit by the workers using Personal Protective Equipment (PPE)

- The implementation of OHSMS is not maximally applied.

Referring to regulation number PER.05/MEN/1996 Appendix II, solutions for those problems above are as follows.

- Conduct strict supervision to ensure that the project is carried out safely.

- Increase the worker's knowledge of OHS through training and motivation.

- The HS signs should be installed properly on the field according to the standard.

- Regular monitoring of project environment and the workers.

- Evaluation towards the effectiveness of OHSMS should be improved.

4. Design and engineering

It has been applied and proved that HIRADC is a reference in the design cycle.

5. Administrative control

It has been applied and proved that the element or planning of OHS has already incorporated into the manufacture of procedures or Work Instruction.

6. Review contract

It has been applied and proved that the contract review has been done to subcontractors and suppliers.

7. Purchases 
It has been applied, proved by the purchasing system that contains procedures to maintenance goods and services that must be integrated with the accident risk prevention procedures and occupational diseases.

8. Dealing with emergencies or disasters procedures

It has been applied and proved that procedures to deal with emergencies or disasters exist.

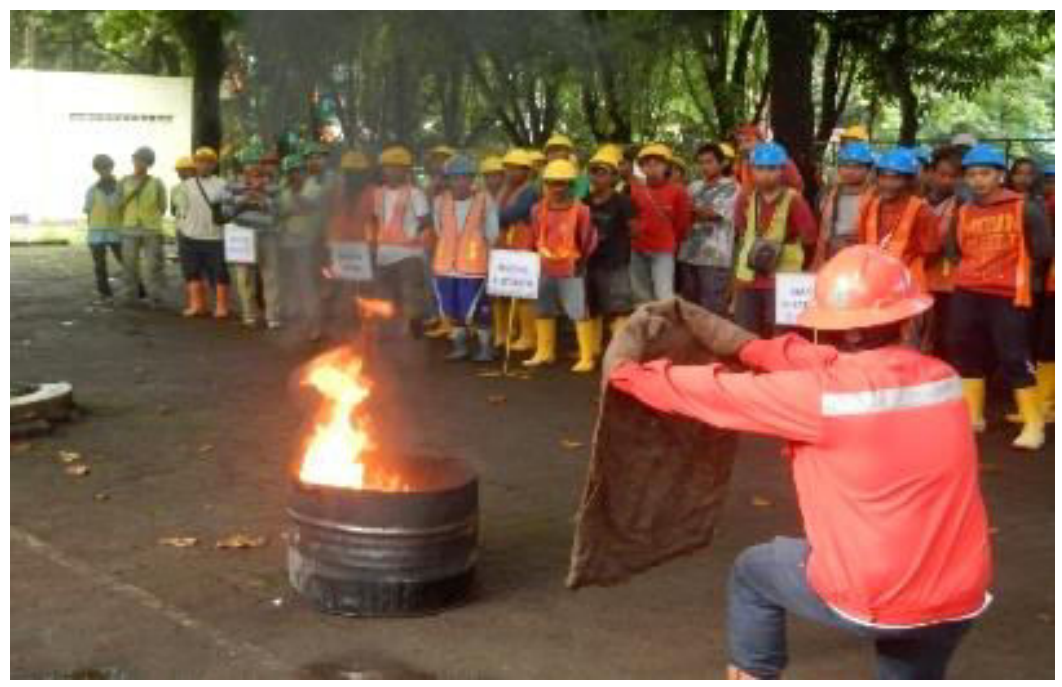

Fig. 5. Fire Fighting Training

9. Procedures to deal with incidents

It has been applied and proved by the existence of Procedure To Deal With Incidents.

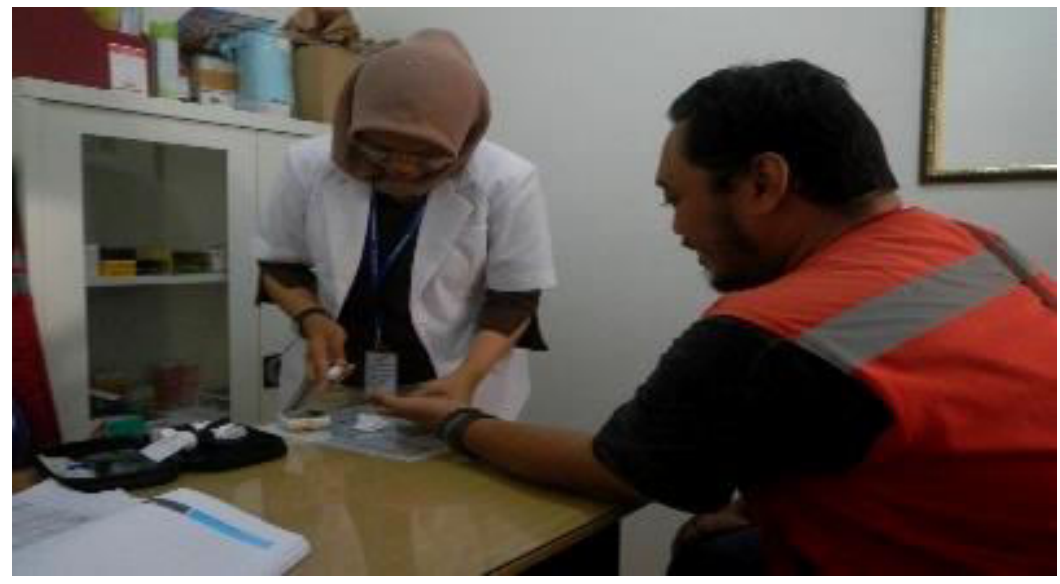

Fig. 6. Medical Check Up in "7 in 1" Project's Clinic

10. Emergency response and recovery plan procedures

It has been applied and proved by emergency response and recovery plan procedures have been applied to the Project. 


\subsubsection{Measurement and Evaluation}

1. Capability Guarantee

a. Inspection and Testing

It has been applied and proved that OHS inspection and testing activities have been conducted in the project

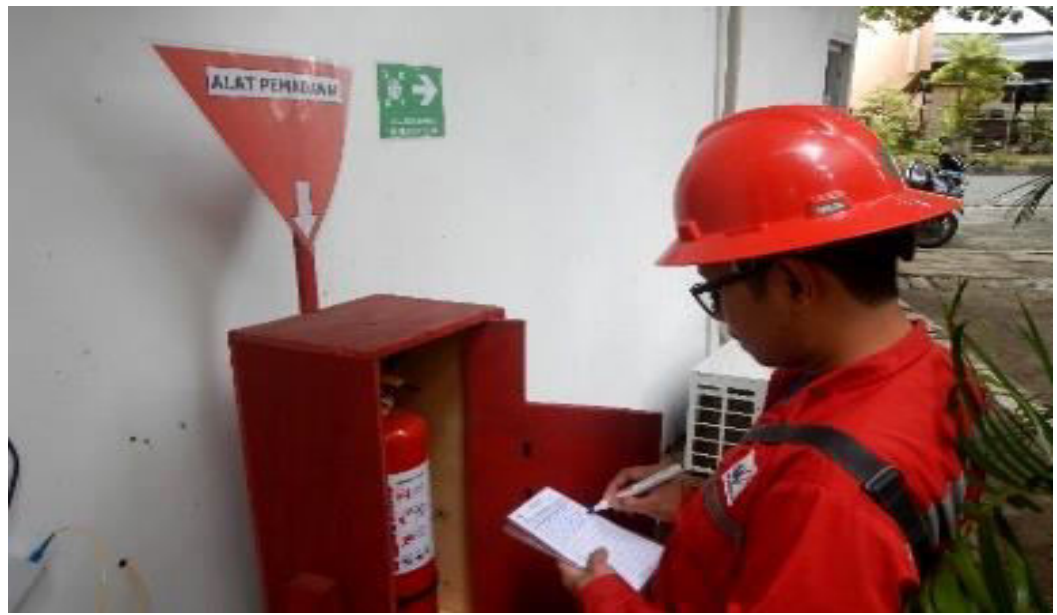

Fig. 7. Inspection and Testing

2. OSH (K3) Management System Audit

It has been applied, proved by the implementation of audit activities by the Internal Supervisory Unit.

3. Corrective and Preventive Measures

It has been applied, proved by the improvement and the prevention act has been done systematically and effectively.

\subsubsection{Review and Improvement by Management}

It has been applied, proved by the implementation of evaluation or review has been conducted regularly by the management regarding OHSMS.

\section{Conclusion and Suggestion}

\subsection{Conclusions}

Based on research that has been done, it can be concluded that the overall implementation of Occupational Health and Safety Management System ( OHSMS) in "7 In 1" Project, Yogyakarta State University, has been running well and it is in accordance with the regulation number PER.05/MEN/1996. Proved by the Company Policy and OHS Program, such as safety briefing and induction to the workers in order to communicate the importance of OHS. In addition, there are several forms as a strong evidence and statements from employees/workers as a confirmation that the project workers have implemented all of the OHSMS elements in the project.

However, still, there are some incidents or non-conformances found in the project that make the implementation of OHSMS on "7 in 1" Project is less than maximal. Incidents that occur in the workplace are workers accidents and detection of unsafe objects. 
Inadequate supervision by the executive, lack of the importance of OHS Awareness, low knowledge workers due to the different educational background, and their undisciplined habits using Personal Protective Equipment (PPE), these are several factors why incidents or non-conformances occur in the project.

\subsection{Suggestions}

There are suggestions to improve better situation toward some problems that were found by researchers at the " 7 in 1 " Project, are as follows.

1. Improve the implementation of the Occupational Health and Safety Management System ( OHSMS) in the ongoing project by adding several programs related to OHS so that the zero accident will be achieved at the project site.

2. Firm action by PT. Waskita Karya (Persero) Tbk as the execution is needed, in conducting supervision especially related to the OHS field to create safe work in the project.

3. The contractor should check the availability of OHS signs and work equipment in the project site whether it is installed properly and correctly.

4. We recommend to improve some socialization and OHS communication activities, such as safety briefing and induction in order to minimize workers' ignorance about their work, and also aim to make workers more aware about the importance of Occupational Health and Safety (OHS).

\section{References}

1. A. Ramadhan, Universitas Indonesia, Penerapan Sistem Manajemen Keselamatan dan Kesehatan Kerja Studi pada Proyek Pembangunan Jalan Rawa Buaya. Cengkareng (2012)

2. B. Endroyo, Jurnal Teknik Sipil, Universitas Negeri Semarang, Peranan Manajemen K3 dalam Pencegahaan Kecelakaan Kerja, Volume III Januari 2006, Page 1 (2006)

3. Republik Indonesia, Peraturan Menteri Tenaga Kerja No. 05 Tahun 1996 tentang Sistem Manajemen Keselamatan dan Kesehatan Kerja (1996)

4. Republik Indonesia, Undang-Undang RI Nomor 1 Tahun 1970 tentang Keselamatan Kerja, Lembaran Negara RI Tahun 1970 No. 1, Tambahan Lembaran Negara RI Tahun 1970 No. 2918 (1970)

5. S. P. Tarigan, Jurnal Teknik Industri, Universitas Sumatera Utara, Analisis Tingkat Penerapan Program Keselamatan Kesehatan Kerja (K3) dengan Pendekatan SMK3 dan Risk Assessment di PT. XYZ, Volume 3, Page 5 (2013)

6. Tarwaka, Harapan Press. Surakarta, Keselamatan dan Kesehatan Kerja Manajemen dan Implementasi K3 Di Tempat Kerja (2008)

7. Y. D. Dwijayanti, Institut Pertanian Bogor, Penerapan Sistem Manajemen Keselamatan dan Kesehatan Kerja (SMK3) pada PT. Suka Jaya Makmur Kalimantan Barat (2012) 